\title{
Program Pemberdayaan Potensi Masyarakat di Desa Bojong Kabupaten NAGREK
}

\author{
${ }^{1}$ Aviasti, ${ }^{2}$ Nugraha, ${ }^{3}$ Dewi Shofi Mulyati, ${ }^{4}$ Reni Amaranti \\ 1,2,3,4 Teknik Industri, Universitas Islam Bandung, Jawa Barat, Indonesia \\ email: 'Aviasti82@gmail.com,2nugraha692016@gmail.com,32dewishofi@gmail.com, \\ ${ }^{4}$ reniamaranti2709@gmail.com
}

\begin{abstract}
The main problem in partner community is the local potential and resources are not utilized in entrepreneurial skills, as well as funds to build productive activities that can improve the familys economic welfare. The main objective of PKM-P3M proposed is the use of less productive land and ex-Lio land. The outputs are: Unproductive land use and use of ex-Lio land through fragrant lemongrass entrepreneurs in Bojong Village, Nagreg Subdistrict, Improving community entrepreneurial skills in land empowerment, and Establishment of business groups to manage commodity entrepreneurship agriculture. The PKM-P3M method applied: Analysis of the situation, Identification of the main problems, Literature study, Identification of solutions offered to partners, Preparation of plans and schedule for the implementation, Technical training and cultivation planting agricultural commodities and its marketing, and Establishment of joint business groups for management and planting. The results are: The community utilizes ex-Lio land by planting fragrant lemongrass and planting corn, The community is very enthusiastic when receiving training, and Farmer groups want to be able to receive good quality fragrant lemongrass seeds.
\end{abstract}

Keywords: Unused land, land use, Community Potential Empowerment Program.

\begin{abstract}
Abstrak. Masalah utama dalam komunitas mitra adalah potensi lokal dan sumber daya tidak dimanfaatkan dalam keterampilan kewirausahaan, serta dana untuk membangun kegiatan produktif yang dapat meningkatkan kesejahteraan ekonomi keluarga. Tujuan utama usulan PKM-P3M adalah penggunaan lahan yang kurang produktif dan lahan bekas Lio. Output : Penggunaan lahan yang tidak produktif dan penggunaan lahan eks-Lio melalui pengusaha serai wangi di Desa Bojong, Kecamatan Nagreg, Meningkatkan keterampilan kewirausahaan masyarakat dalam pemberdayaan lahan, dan Pembentukan kelompok bisnis untuk mengelola komoditas pertanian kewirausahaan pertanian. Metode PKM-P3M yang diterapkan: Analisis situasi, Identifikasi masalah utama, Studi literatur, Identifikasi solusi yang ditawarkan kepada mitra, Persiapan rencana dan jadwal untuk implementasi, Pelatihan teknis dan penanaman komoditas pertanian dan pemasarannya, dan Pendirian kelompok usaha bersama untuk pengelolaan dan penanaman. Hasil : Masyarakat memanfaatkan lahan bekas Lio dengan menanam serai wangi dan menanam jagung, masyarakat sangat antusias ketika menerima pelatihan, dan kelompok tani ingin dapat menerima benih serai wangi yang berkualitas baik.

Kata kunci: Lahan yang tidak digunakan, penggunaan lahan, Program Pemberdayaan Potensi Masyarakat.
\end{abstract}

\section{Pendahuluan}

Bata adalah salah satu bahan untuk pembuatan bahan dinding. Batu bata terbuat dari tanah liat yang dibakar hingga warna kemerahan. Industri batu bata selain memberikan kontribusi pada sebagian besar pendapatan juga menyebabkan kerusakan lingkungan akibat eksploitasi berkelanjutan. Banyak 
bukit rusak dan tanah menjadi tidak subur karena digunakan sebagai bahan baku pembuatan batu bata. Hal-hal seperti itu banyak terjadi di banyak tempat, salah satunya adalah Desa Bojong, di mana sebagian besar mata pencaharian masyarakat adalah pengrajin batu bata merah, menghasilkan pekerja yang mengekstraksi bahan baku untuk batu bata merah. Namun, di beberapa bagian Desa Bojong masih ada lahan kosong yang belum dimanfaatkan dengan baik. Tanah kosong dibiarkan tanpa menghasilkan apa pun yang memiliki nilai tambah. Kedua hal ini membutuhkan perhatian dan penanganan yang tepat agar bermanfaat untuk meningkatkan pendapatan dan tidak menjadi hambatan dalam meningkatkan kesejahteraan ekonomi warga Desa Bojong secara umum.

Upaya-upaya perlu dilakukan dalam bentuk kegiatan pengabdian masyarakat untuk Program Pemberdayaan Potensi Masyarakat (PKM-P3M) melalui penggunaan lahan tidak produktif, terutama produksi batu bata merah sehingga diharapkan dapat meningkatkan ekonomi dan kesejahteraan masyarakat setempat, peluang, peningkatan nilai tambah dan daya saing, sebaik pendapatan petani penghasil minyak atsiri.

Secara umum kondisi sosial ekonomi Kabupaten Bojong Nagreg relatif rendah, dari total 5.885 penduduk sebagian besar mata pencaharian utama berasal dari industri pembuatan batu bata merah. Kondisi ini merupakan kendala dalam meningkatkan kesejahteraan ekonomi, di sisi lain ada potensi lahan menganggur yang belum dieksploitasi sebaik jumlah lahan bekas galian untuk membuat batu bata merah. Selain masih banyak lahan tidak produktif, terdapat pula kekurangan bimbingan kewirausahaan dan teknik budidaya tanah. Untuk tujuan ini, layanan masyarakat diperlukan melalui penggunaan lahan yang kurang produktif, terutama bekas penggalian bata merah sehingga diharapkan dapat meningkatkan ekonomi dan kesejahteraan masyarakat setempat.

\section{Metode}

Referensi yang terkait dengan hasil studi empiris proposal pengabdian masyarakat (PKM) diusulkan sebagai berikut :

1. Agus Hasanuddin $\mathrm{R}$, et al. (2010), Standar Operasional Prosedur Budidaya Tanaman Seraiwangi , Direktorat Budidaya Tanaman Tahunan Direktorat Jendral Perkebunan bekerjasama dengan Lembaga Penelitian untuk Tanaman Obat dan Aromatik.

2. Aviasti, dkk. (2016), Pemberdayaan Potensi Masyarakat di Desa Cimungkal, Kecamatan Wado Melalui Kewirausahaan Serai Wangi, Laporan Akhir PKM-P3M. Hibah LPPM Universitas Islam Bandung.

3. Dzikron, M. Dan Aswardi Nasution, 2012, Peningkatan Proses Produksi dan Penerapan Teknologi Tepat Guna Keripik Singkong di Desa Cijambe, Kab. Sumedang, Laporan Akhir IbM, Hibah Desentralisasi Dikti, Kementrian Pendidikan Nasional.

4. Marlon L.P (2012) Penerapan Perlakuan Bahan Baku dan Metode Penyulingan Uap Air untuk Hasil dan Sifat Organoleptik Minyak Atsiri.

Yuni Eko Feriyanto, dkk (2013) Studi Ekstraksi Minyak Esensial dari Daun Wangi dan Serai Menggunakan Metode Penyulingan Uap dan Air dengan Pemanasan Microwave. Jurnal produksi Bersih, 87, Halaman 318-327. 


\section{Tanaman Serai Wangi}

Serai wangi adalah tanaman dari keluarga rumput. Tumbuhan ini memiliki nama lain Cymbopogon nardus, tumbuh hingga ketinggian sekitar 50-100 cm. Daun tunggal berjumbai seperti pita hingga panjang 1 meter dan lebar 1,5 cm. Daun sereh terlihat hijau atau hijau kebiruan. Batangnya tidak berkayu, bergaris, dan putih. Tanaman serai wangi berkembang biak dengan sistem tunggul akar. Bahanbahan: Tanaman yang mengandung geraniol, methylheptenone, terpene, terpene, alkohol, asam organik, dan terutama serai.

Serai wangi tumbuh dengan baik pada suhu $18-25{ }^{\circ} \mathrm{C}$ dan pada ketinggian 350 - 600 di atas permukaan laut dengan pH sekitar 6-7,5 (Suroso, 2018). Kebanyakan orang mengetahui serai wangi sebagai penyedap makanan yang memberi rasa dan aroma pada makanan. Hanya sebagian kecil yang mengetahui manfaat serai sebagai bahan baku minyak serai yang bernilai tinggi dibandingkan dengan hanya menjadi bumbu dapur. Minyak serai yang diproduksi oleh serai wangi memiliki berbagai kegunaan termasuk bahan baku untuk industri kosmetik, sari, parfum, bahan-bahan pewangi, industri farmasi, obat-obatan tradisional, minyak gosok, insektisida, penolak nyamuk dan lainlain. Tanaman sereh wangi di Indonesia memiliki nama berbeda, disebut serai (Jawa, Madura, Sunda, Gayo), sarai (Minang), sorai (Lampung), see (Bali), bibirampori (Bima), kedoung witu (Sumba), nou sina ( Pulau Roti) dan tenian nalai (Pulau Leti). Tanaman serai wangi di mancanegara dikenal dengan sebutan rumput serai.

\section{Kewirausahaan Komoditas Agroindutri Serai Wangi}

Aktivitas yang diusulkan dalam Kegiatan PKM ini dimulai dengan analisis lingkungan bisnis yang terkait dengan kewirausahaan minyak serai wangi meliputi: (1) Memberdayakan lahan yang kurang produktif untuk dioptimalkan dengan menanam serai wangi. Tahapan budidaya meliputi kegiatan-kegiatan: persiapan biji serai wangi, pengolahan tanah, pembibitan, penanaman, pemeliharaan hingga panen dalam siklus 6 bulan ; (2) Perencanaan bisnis Agroindustri Minyak Serai wangi

Kegiatan pemberdayaan agroindustri serai wangi dimulai dengan analisis lingkungan yang meliputi pertimbangan aspek sosial-ekonomi, pengembangan lahan potensial dan masyarakat lokal melalui kegiatan PKM, pengolahan bahan baku serai wangi hingga tahap pemasaran dan penjualan produk. Idealnya, tahap-tahap PKM ini perlu dilakukan secara terus menerus selama tiga tahun ke depan, sehingga pengembangan kewirausahaan bagi masyarakat dapat didampingi oleh tim proposal PKM hingga ke pasar atau konsumen.

Beberapa langkah teknis untuk memulai bisnis minyak serai : tentukan lini bisnis yang akan dijalani; merencanakan visi, misi, dan program kerja; merancang produk dan proses produksi; menyiapkan modal (baik sumber daya manusia atau uang untuk mendukung proses produksi), menghitung kebutuhan investasi, biaya produksi dan proyeksi untung rugi; mengurus izin usaha produksi; uji coba produksi dan uji coba pemasaran produk (LIPI Press, 2019).

\section{Pemberdayaan Potensi Masyarakat}

Banyak ahli telah menggambarkan arti pemberdayaan masyarakat. Rappaport mendefinisikan pemberdayaan sebagai cara di mana orang, organisasi dan masyarakat diarahkan sehingga mereka dapat mengatur hidup mereka (Anonim 1). 
Payne mendefinisikan bahwa pemberdayaan masyarakat dimaksudkan untuk membantu klien mendapatkan kekuatan untuk membuat keputusan dan menentukan tindakan yang akan dilakukan terkait dengan diri mereka sendiri, meliputi pengurangan efek pribadi dan hambatan sosial (Mustangin, dkk., 2017). UNICEF mengusulkan 5 dimensi sebagai tolok ukur untuk keberhasilan pemberdayaan masyarakat, yang terdiri dari kesejahteraan, akses, kesadaran kritis, partisipasi dan kenndali. Kelima dimensi tersebut adalah kategori analisis dinamis, saling terkait secara sinergis, saling menguatkan dan saling melengkapi satu sama lain (Anonim 1).

\section{Hasil dan Pembahasan}

Untuk mengetahui kondisi awal mitra PKM yang menjadi objek PKM, dilakukan studi lapangan pendahuluan. Studi pendahuluan ini dilakukan dengan pengamatan langsung terhadap objek penelitian, yaitu Desa Bojong, Kecamatan Nagrek, dengan melakukan wawancara dan juga mempelajari dokumen yang berkaitan dengan objek penelitian. Berdasarkan hasil studi literatur, informasi berikut diperoleh : Desa Bojong adalah satu dari delapan (8) desa di Kecamatan Nagreg, Kabupaten Bandung dengan luas 756 hektar atau sekitar 19,51\% dari wilayah administrasi Kabupaten Nagreg (dapat dilihat pada Gambar 1). Desa Bojong berjarak sekitar $58 \mathrm{~km}$ dari kota Garut dan dicirikan sebagai desa tradisional yang cenderung urban, ditandai dengan keragaman dalam hal komposisi masyarakat, tingkat pendidikan, dinamika masyarakat, mata pencaharian masyarakat dalam hal organisasi, baik dalam bentuk lembaga sosial dan lembaga pemerintah (kkn .uinsgd).

Wilayah Desa Bojong berupa lereng / punggung bukit yang terletak di tepi / sekitar kawasan hutan dengan ketinggian 707 meter di atas permukaan laut. Desa Bojong terdiri dari 1.729 kepala keluarga dengan total populasi 5.885 orang (BPS Kabupaten Bandung, 2016). Secara umum, kondisi sosial ekonomi penduduk desa Bojong relatif rendah dengan mata pencaharian dasar sebagian besar adalah petani atau buruh tani meskipun kondisi kontur tanah dan cuaca di Desa Bojong kurang cocok untuk pertanian seperti sayuran dan komoditas pertanian dengan panen pendek. Saat ini pendapatan tertinggi Desa Bojong berasal dari industri bata merah / keramik. Jumlah industri bata merah / keramik sekitar 150 dengan kontribusi pendapatan desa sekitar $80 \%$.

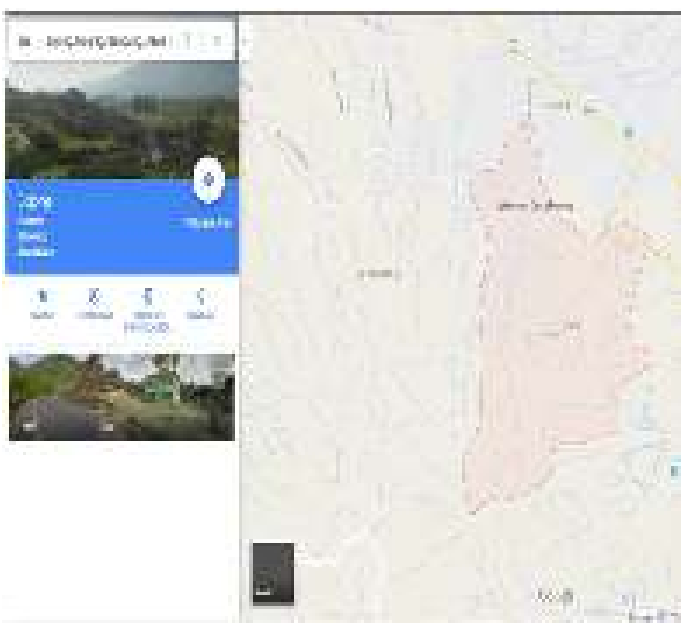

Gambar 1. Peta Lokasi Desa Bojong

Pengrajin Bata Merah di Desa Bojong, Kecamatan Nagreg, Kabupaten Bandung mengalami penurunan setiap tahun. Pengurangan pengrajin Bata Merah dikarenakan tanah yang digunakan untuk membuat bata merah sudah mulai habis. Menurut informasi, keberadaan pengrajin Bata Merah di Desa Bojong kini tersisa 60 persen.

\section{Wirausaha Serai Wangi}

Kegiatan yang dilakukan untuk P3M PKM meliputi : (1) Pelatihan teknis dan penanaman : menanam serai, teknik pengilangan minyak serai wangi dan 
pemasaran. Secara umum, metode pemurnian minyak serai dapat dilakukan dengan cara : a) penyulingan dengan air, b) penyulingan dengan air dan uap dan c) penyulingan uap langsung. Penggunaan metode dipilih berdasarkan pertimbangan karakteristik bahan baku minyak, proses difusi minyak dengan air panas, dekomposisi minyak akibat efek panas, efisiensi produksi, dan keefektifan ekonomi dan produksi (LIPI Press, 2019) ; (2) Pembentukan kelompok usaha gabungan untuk pengelolaan dan penyulingan minyak serai, membantu usaha patungan, memelopori pembentukan koperasi, memantau kegiatan usaha gabungan dan merumuskan tindakan pengembangan wirausaha serai wangi.

Kegiatan yang dilakukan meliputi : (1) Survei pendahuluan untuk melihat tempat penyulingan serai wangi di Desa Bojong dan mencari waktu untuk melangsungkan pelatihan bagi masyarakat Desa Bojong. Tim bertemu dengan salah satu petani serai, yang mengatakan bahwa kilang sementara tidak berjalan, karena kekurangan bahan baku, yaitu serai wangi. Saat ini petani yang menanam serai wangi berkurang karena benih yang ditanam tidak seperti yang diharapkan (Dapat dilihat pada gambar 2 \& gambar 3) ; (2) Bertemu dengan Kepala Desa Bojong dan masyarakat setempat untuk mengidentifikasi potensi masyarakat setempat terutama dalam memanfaatkan lahan yang tidak produktif. Berdasarkan hasil diskusi, diperoleh informasi berikut: Desa Bojong memiliki luas sekitar 756 hektar dengan populasi 6738 orang, ada 4 dusun, 10 RW dan 41 RT. Mata pencaharian masyarakat Desa Bojong terdiri dari pengrajin batu bata merah, pekerja konstruksi dan karyawan pabrik. Sekitar tahun 1980, komunitas Desa Bojong adalah $80 \%$ pengrajin batu bata merah, tetapi sekarang mereka beralih ke Pertanian; (3) Pelatihan untuk kelompok tani dan pengrajin Bata Merah dengan materi pelatihan teknik penanaman dan teknik destilasi serai wangi, terutama mengenai persyaratan untuk menumbuhkan dan menanam serai wangi dan produksi minyak serai wangi. Pelatihan ini diikuti oleh sekitar 40 petani ; (4) Menyediakan pelatihan kepada kelompok tani dengan materi pemasaran melalui internet. Dalam pelatihan ini, diharapkan kelompok tani dapat mengetahui kondisi pasar minyak serai wangi sehingga petani dapat menangkap peluang pasar yang ada, dan untuk meningkatkan kesejahteraan kelompok tani. Selain itu, petani diharapkan dapat mempromosikan dan atau menjual produk mereka tidak hanya secara langsung tetapi juga dapat menjualnya melalui media internet. Bisnis budidaya dan pemurnian serai membutuhkan perencanaan yang cermat terkait dengan kesesuaian budidaya, kelayakan industri penyulingan, dan integrasinya ke arah yang lebih menguntungkan. Untuk memulai pengembangan dan pengelolaan bisnis minyak serai dan produk turunannya, langkah-langkah dan pendekatan manajemen yang sistematis, terintegrasi dan berkelanjutan diperlukan. Para pelaku perlu secara aktif memperhatikan potensi pasar, memeriksa siklus hidup produk, merumuskan desain produk, membangun rantai pasokan yang kuat dan memelihara peralatan produksi (LIPI Press, 2019) ; (5) Mengevaluasi hasil pelatihan dengan mitra dan kelompok tani. Pada sesi terakhir pelatihan, tim, mitra dan kelompok tani mengevaluasi hasil pelatihan dan hambatan yang dihadapi oleh kelompok tani ketika melakukan budidaya serai (masalah teknis yang dapat muncul adalah jumlah bahan baku yang tidak memadai , pemilihan lokasi dan pemilihan air). Hasilnya diperoleh bahwa mereka tidak sepenuhnya ingin membudidayakan serai karena mereka 
belum mendapatkan biji yang cukup baik, dan mereka berharap bahwa dalam kegiatan PKM berikutnya mereka dapat menerima biji sereh wangi yang berkualitas.

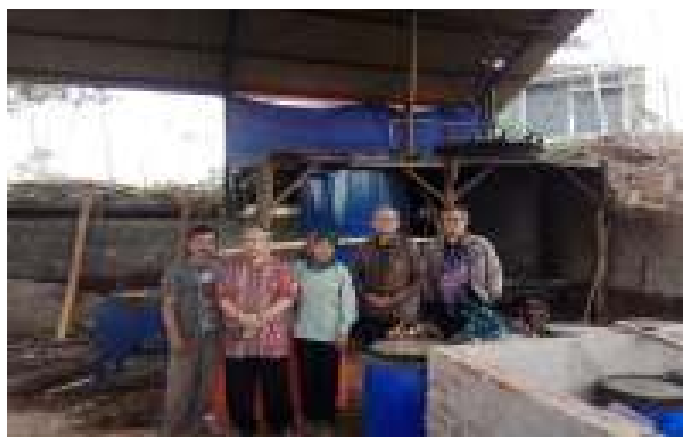

Gambar 2. Lokai Pengilangan Minyak Serai Wangi

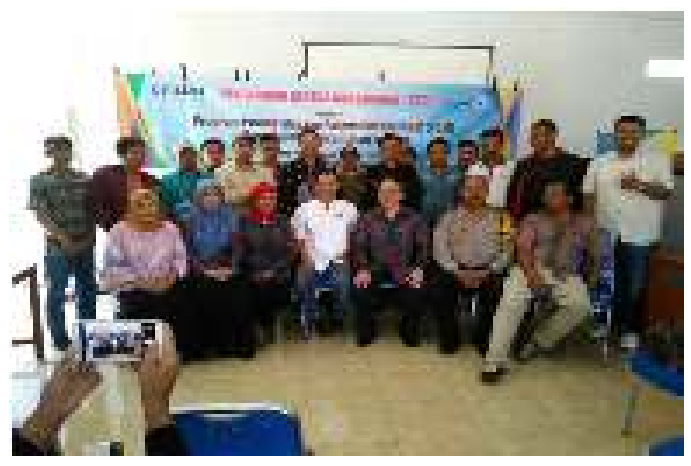

Gambar 3. Anggota Pelatihan dan Tim

\section{Kesimpulan dan Saran}

Kesimpulan yang didapatkan dari hasil pengabdian kepada masyarakat meliputi : (1) Kelompok tani di Desa Bojong tertarik dalam pembudidayaan serai walaupun menghadapi kendala terutama pada musim hujan yang dapat berakibat pada biaya operasional yang tinggi, selain itu juga sulit mendapatkan benih sereh wangi yang memenuhi persyaratan untuk menghasilkan produk yang berkualitas tinggi, (2) Pelatihan yang disediakan diharapkan menghasilkan perubahan dalam sikap atau kecakapan hidup masyarakat yang diukur dengan penguasaan / peningkatan keterampilan praktis dan / atau teoritis (tidak berwujud). Kegiatan P3M PKM diharapkan dapat meningkatkan keterampilan kewirausahaan masyarakat dalam pemberdayaan lahan, tidak hanya untuk budidaya serai wangi tetapi juga untuk budidaya tanaman lain yang sesuai dengan kondisi tanah galian bata merah sebelumnya, (3) Pembentukan usaha gabungan untuk kelompok petani dalam hal penanaman serai wangi atau bisnis lain sesuai dengan potensi sumber daya yang tersedia di Desa Bojong.

\section{Ucapan Terimakasih}

Pada kesempatan ini kami ingin mengucapkan terima kasih kepada Lembaga Penelitian dan Pengabdian kepada Masyarakat (LPPM) UNISBA, karena penelitian ini dapat dilakukan dengan hibah dari LPPM UNISBA 2018 melalui proses pemilihan proposal penelitian pada tahun 2017.

\section{DAFTAR PUSTAKA}

Agus Hasanuddin R, dkk. (2010), Standar Operasional Prosedur Budidaya Tanaman Seraiwangi, Direktorat Budidaya Tanaman Tahunan Direktorat Jendral Perkebunan bekerjasama dengan Lembaga Penelitian untuk Tanaman Obat dan Aromatik.

Anonim

(http://digilib.uinsby.ac.id/402/5/Ba b\%202.pdf diakses pada 12 Maret 2020)

Aviasti, Aviasti ; Nugraha ; Rukmana, Asep Nana ; Nurahman, Ahmad Arif. (2016), Pemberdayaan Potensi Masyarakat di Desa Cimungkal, Kecamatan Wado Melalui Kewirausahaan Serai Wangi, Laporan Akhir PKM-P3M. Hibah LPPM Universitas Islam Bandung.

BPS Kabupaten Bandung, 2016.

Dzikron, M. and Aswardi Nasution, (2012), Peningkatan Proses Produksi dan Penerapan Teknologi Tepat Guna Keripik Singkong di Desa Cijambe, Kab. Sumedang, Laporan Akhir IbM, Hibah Desentralisasi 
Dikti, Kementrian Pendidikan Nasional.

Feriyanto, Yuni Eko ; Sipahutar, Patar Jonathan ; Mahfud, Mahfud ; Prihatini, Pantjawarni (2013) Studi Ekstraksi Minyak Esensial dari Daun Wangi dan Serai Menggunakan Metode Penyulingan Uap dan Air dengan Pemanasan Microwave. Jurnal produksi Bersih, 87, Halaman 318-327.

Kkn.uinsgd. Desa Bojong Kecamatan Nagrek Kabupaten Bandung. (https://kkn.uinsgd.ac.id/desabojong /desa-bojong/) diakses pada 10 Maret 2020.

LIPI Press (2019). Minyak Serai Wangi dan Produk Turunannya. LIPI Press : Jakarta.

Marlon (2012), Penerapan Perlakuan Bahan Baku dan Metode Penyulingan Uap Air untuk Hasil dan Sifat Organoleptik Minyak Atsiri.

Mustangin ; Kusniawati, Desy ; Islami, Nufa Pramina ; Setyaningrum, Baruna ; Prasetyawati, Eni (2017). Pemberdayaan Masyarakat Berdasarkan Potensi Lokal Melalui Program Pariwisata Desa di Desa Bumiaji. Jurnal Pemikiran dan Penelitian Sosiologi, Vol. 2 No.1.

Suroso (2018). Budidaya Serai Wangi. Dinas Kehutanan Dan Perkebunan Daerah Istimewa Yogyakarta. 